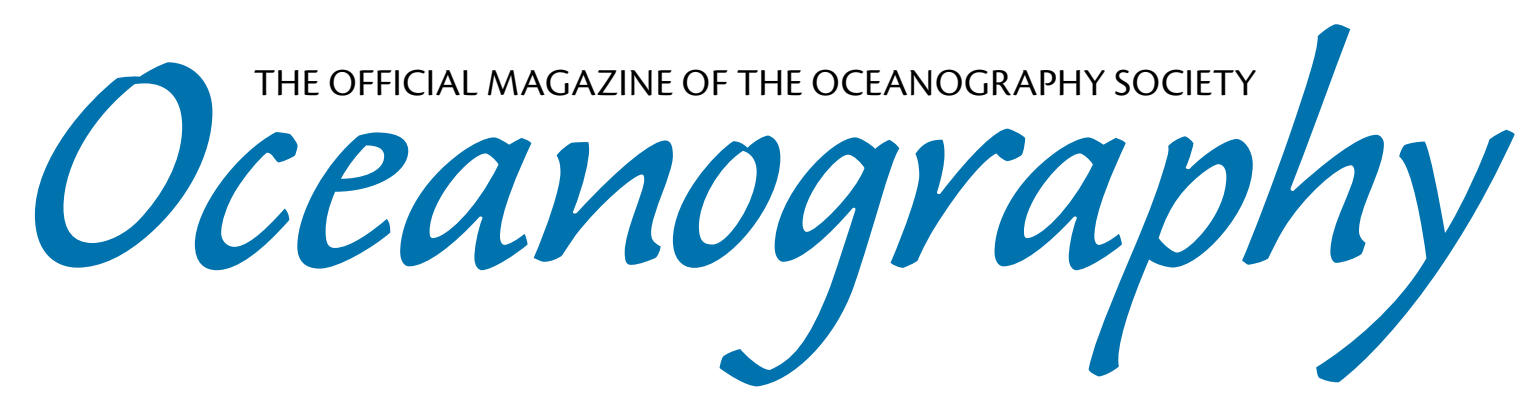

CITATION

Bemis, K., R.P. Lowell, and A. Farough. 2012. Diffuse flow on and around hydrothermal vents at mid-ocean ridges. Oceanography 25(1):182-191, http://dx.doi.org/10.5670/oceanog.2012.16.

$\mathrm{DOI}$

http://dx.doi.org/10.5670/oceanog.2012.16

COPYRIGHT

This article has been published in Oceanography, Volume 25, Number 1, a quarterly journal of The Oceanography Society. Copyright 2012 by The Oceanography Society. All rights reserved.

USAGE

Permission is granted to copy this article for use in teaching and research. Republication, systematic reproduction, or collective redistribution of any portion of this article by photocopy machine, reposting, or other means is permitted only with the approval of The Oceanography Society. Send all correspondence to: info@tos.org or The Oceanography Society, PO Box 1931, Rockville, MD 20849-1931, USA. 


\section{Diffuse Flow \\ On and Around Hydrothermal Vents at Mid-Ocean Ridges}

BY KAREN BEMIS, ROBERT P. LOWELL, AND AIDA FAROUGH

ABSTRACT. Black smokers are the dramatic result of seawater being heated to high temperatures (generally $250^{\circ}$ to $350^{\circ} \mathrm{C}$ ) by magmatic systems, then discharging at the seafloor. However, not all seawater that circulates through the oceanic crust is heated to high temperatures. "Diffuse flow" is a catchall term to describe lowtemperature $\left(<0.2^{\circ}\right.$ to $\left.\sim 100^{\circ} \mathrm{C}\right)$ fluids that slowly discharge through sulfide mounds, fractured lava flows, and assemblages of bacterial mats and macrofauna. Diffuseflow fluids are generally mixtures of cold seawater and either magmatically heated fluids, conductively heated seawater, or both. Although the limited data indicate that $50-90 \%$ of the hydrothermal heat loss occurs as diffuse flow at the seafloor, modeling results coupled with geochemical data suggest that nearly $90 \%$ of the heat loss ultimately stems from magmatically heated fluids. There is a critical need to obtain more diffuse-flow measurements to improve models of heat and geochemical fluxes, better understand subsurface fluid flow dynamics, and determine the extent of the subsurface biosphere as well as the spatial and temporal variability of diffuse flow. New measurement techniques and diffuse-flow models provide insight into the characteristics of these subsurface fluids and their manifestation at the seafloor. 


\section{INTRODUCTION}

Seafloor hydrothermal systems at midocean ridges are places where seawater, heated and made buoyant by interaction with magmatic systems, discharges onto the seafloor. Much attention has focused on deeply circulating and highly heated fluids that vent directly to the seafloor as black smokers. However, far more seawater circulates in the shallow subsurface and discharges much less dramatically as mildly heated (up to $\sim 100^{\circ} \mathrm{C}$ ) diffuse flow. These discharges exhibit such a great variety of forms that they are difficult to characterize. For example, there are slow leakages of low-temperature fluids through sulfide mounds and chimneys associated with the high-temperature black smokers, and there are slow discharges associated with fissures and fractures in the seafloor. Frequently, the fauna and microbial mats of hydrothermal sites obscure the details of the discharging diffuse flow that supports such biological productivity.

Although the importance of diffuse flow is well recognized, quantitative characterization of diffuse venting has remained elusive. However, since the initiation of the Ridge 2000 Program, we have come to understand more fully that a significant portion of the heat transported by deep fluid circulation is discharged as low-temperature fluids (Farough, 2011; Germanovich et al., 2011). In this paper, we describe variations in venting style, flow rate, and associated geologic structures through a survey of data collected at various sites. We also discuss several recently developed tools that measure fluid flow velocity, volume flux, and heat flux at diffuse venting sites. Our emphasis is on magmatically driven hydrothermal systems and the partitioning of heat and chemical fluxes between focused and diffuse venting. Finally, we briefly summarize some methods of modeling diffuse flow and how these models may be used to estimate the extent of the subsurface biosphere.

\section{WHAT IS DIFFUSE FLOW?}

No single definition of diffuse flow can be easily crafted. The classic definition of diffuse flow is fluids discharged along mid-ocean ridge axes that have low temperatures (at least relative to black smokers and flanges), low flow rates, and broad spatial distributions. Mechanisms cited to explain the small, but real, temperature anomalies associated with diffuse fluid discharges include mixing of seawater with high-temperature hydrothermal fluids, conductive cooling of high-temperature fluids, heating by exothermic geochemical reactions (e.g., serpentinization), and conductive heating of seawater (Cooper et al., 2000; Kelley et al., 2002; Lowell et al., 2008; Foustouskos et al., 2009). These processes and reactive transport with the surrounding subsurface rock (usually basalt) affect the chemistry of diffuse fluids (Crowell et al., 2008; Foustouskos et al., 2009). At present, we do not have

OPPOSITE PAGE | Vigorous, "milky" diffuse flow adjacent to a high-temperature vent (small spindly chimney on the right in the image) at the top of Tubeworm Pillar at $9^{\circ} 49.6^{\prime} \mathrm{N}$ in the axial summit trough of the East Pacific Rise crest. Diffuse flow is providing habitat for dense aggregations of Riftia pachyptila. Image collected from Alvin in November 1999, courtesy of Tim Shank, Woods Hole Oceanographic Institution, The Stephen Low Co., and Rich Lutz, Rutgers University

consistent terminology to distinguish between (a) flows whose temperature anomalies derive from the mixing of high-temperature fluids with seawater (whether in a subsurface reservoir or within a sulfide mound), and (b) flows whose temperature anomalies derive from the conduction of heat (either from a deeper heat source or from inside a sulfide mound).

There are only limited data concerning the properties of diffuse flow, and the data that exist (Table 1) provide only limited support for the classic definition of diffuse flow. Measured temperature anomalies at diffuse sites, which range from $<0.2^{\circ}$ to $81^{\circ} \mathrm{C}$, are significantly lower than the temperatures measured at black smokers and flanges (which are usually above $250^{\circ} \mathrm{C}$ ), but many sites report significant temporal and spatial variations in temperature (Tivey et al., 2002; Sohn, 2007). Measured flow rates vary even more from $0.0001 \mathrm{~m} \mathrm{~s}^{-1}$ to $0.15 \mathrm{~m} \mathrm{~s}^{-1}$ (Table 1), and the high end of this range overlaps with the bottom end of the range for black smokers $\left(0.1-6.2 \mathrm{~m} \mathrm{~s}^{-1}\right.$; see review in Ramondenc et al., 2006). Finally, while no systematic surveys have attempted to measure the areal distribution of diffuse flow quantitatively, Shank et al. (1998) come closest to a spatial survey in their mapping of the incidence of biota inhabiting diffuse flow patches along the ridge axis at $9^{\circ} \mathrm{N}$ on the East Pacific Rise (EPR). Most other studies simply report the size of the diffuse-flow patch in which their measurements were made. Even with substantial watercolumn mixing with seawater, diffuseflow plumes can be traced for extended distances (e.g., $\sim 1 \mathrm{~km}$ in Trivett and Williams, 1994). 


\section{VENTING STYLES}

Venting of diffuse flows takes many forms. At many sites, discharge occurs through cracks in lava flows (Butterfield et al., 2004; Pruis and Johnson, 2004;
Shank et al., 1998; Sohn, 2007). One example of this style of flow is where white hydrothermal deposits, which are not commonly visible, line cracks in the seafloor around the ASHES vent field on Axial Volcano on the Juan de Fuca Ridge (Figure 1A; Pruis and Johnson, 2004). Diffuse flow is also often observed as shimmering water spread over larger areas, especially in association with lava

Table 1. Key published data on diffuse flow from various mid-ocean ridge sites

\begin{tabular}{|c|c|c|c|c|c|c|c|c|}
\hline Location & $\begin{array}{l}\text { Type of diffuse } \\
\text { structure }\end{array}$ & $\begin{array}{l}\text { Temper- } \\
\text { ature } \\
\left({ }^{\circ} \mathrm{C}\right)\end{array}$ & $\begin{array}{l}\text { Diffuse flow } \\
\text { velocity } \\
\left(\mathrm{m} \mathrm{s}^{-1}\right)\end{array}$ & $\begin{array}{l}\text { Area of } \\
\text { diffuse } \\
\text { flow } \\
\left(\mathrm{m}^{2}\right)\end{array}$ & $\begin{array}{l}\text { Total diffuse } \\
\text { heat output } \\
\qquad(\mathrm{MW})^{1}\end{array}$ & $\begin{array}{l}\text { Ratio of } \\
\text { diffuse to } \\
\text { total heat } \\
\text { flux }\end{array}$ & $\begin{array}{l}\text { Physical data } \\
\text { references }\end{array}$ & $\begin{array}{l}\text { Chemical data } \\
\text { references }\end{array}$ \\
\hline \multicolumn{9}{|c|}{ Juan de Fuca Ridge (JdFR) } \\
\hline \multirow{2}{*}{$\begin{array}{c}\text { Axial } \\
\text { Seamount }\end{array}$} & \multirow{2}{*}{$\begin{array}{l}\text { Fracture networks, } \\
\text { discrete cracks } \\
\text { or holes, sulfide } \\
\text { edifices }\end{array}$} & & $5 \times 10^{-4}$ to 0.14 & $\begin{array}{l}200 x \\
1,200\end{array}$ & 0.2 to 0.3 & & $\begin{array}{l}\text { Pruis and Johnson } \\
\qquad(2004)\end{array}$ & \multirow{2}{*}{$\begin{array}{c}\text { Butterfield et al. } \\
(1990,2004)\end{array}$} \\
\hline & & Up to 27 & 0.05 to 0.1 & & 15 to 75 & 0.9 & $\begin{array}{l}\text { Rona and Trivett } \\
(1992)\end{array}$ & \\
\hline \multirow{2}{*}{$\begin{array}{c}\text { Main } \\
\text { Endeavour } \\
\text { Field (MEF) }\end{array}$} & \multirow{2}{*}{$\begin{array}{l}\text { Sulfide edifice, tube- } \\
\text { worms patches }\end{array}$} & 7 to 13 & 0.07 to 0.15 & 20 & 0.5 to 10 & 0.9 & $\begin{array}{l}\text { Schultz et al. } \\
\text { (1992) }\end{array}$ & \multirow{2}{*}{$\begin{array}{l}\text { Foustoukos et al. } \\
\qquad(2009)\end{array}$} \\
\hline & & & & & 300 & 0.5 & Veirs et al. (2006) & \\
\hline $\begin{array}{l}\text { MEF and } \\
\text { Mothra }\end{array}$ & Varies & 9 to 81 & 0.01 to 0.1 & & & & $\begin{array}{l}\text { Wankel et al. } \\
\text { (2011) }\end{array}$ & \\
\hline \multirow{2}{*}{ Cleft site } & \multirow{2}{*}{ Sulfide mounds } & & & & 534 & 0.7 & Baker et al. (1993) & \\
\hline & & 2 to 15 & - & & & & Tivey et al. (2002) & \\
\hline $\begin{array}{l}\text { Southern } \\
\text { JdFR }\end{array}$ & Fracture & $\begin{array}{c}1.88 \text { to } \\
1.98\end{array}$ & & & 12 and 125 & & $\begin{array}{c}\text { Trivett and } \\
\text { Williams (1994) }\end{array}$ & \\
\hline \multicolumn{9}{|c|}{ Mid-Atlantic Ridge (MAR) } \\
\hline \multirow{3}{*}{$\begin{array}{l}\text { Trans- } \\
\text { Atlantic } \\
\text { Geotraverse } \\
\text { (TAG) }\end{array}$} & \multirow{3}{*}{$\begin{array}{l}\text { Discrete cracks and } \\
\text { vents on sulfide } \\
\text { mound }\end{array}$} & $14 \pm 0.5$ & $(5 \pm 4) \times 10^{-4}$ & & & & $\begin{array}{l}\text { Schultz et al. } \\
(1996)\end{array}$ & \\
\hline & & & & & 250 to 470 & & $\begin{array}{l}\text { Rudnicki and } \\
\text { Elderfield (1992) }\end{array}$ & \\
\hline & & & & & $460 \pm 40$ & 0.8 & $\begin{array}{l}\text { Goto et al. } \\
(2003,2007)\end{array}$ & \\
\hline \multirow{2}{*}{ Lucky Strike } & \multirow{2}{*}{$\begin{array}{l}\text { Tour Eiffel sulfide } \\
\text { edifice }\end{array}$} & 4.5 to 16.4 & $\begin{array}{l}1 \times 10^{-4} \text { to } \\
4.9 \times 10^{-4}\end{array}$ & & & & $\begin{array}{l}\text { Sarrazin et al. } \\
\quad(2009)\end{array}$ & \multirow{2}{*}{$\begin{array}{l}\text { Cooper et al. } \\
\quad(2000)\end{array}$} \\
\hline & & 10 to 15 & $>0.04$ & & & & $\begin{array}{l}\text { Mittelstaedt et al. } \\
(2010)\end{array}$ & \\
\hline \multicolumn{9}{|c|}{ East Pacific Rise (EPR) } \\
\hline $9^{\circ} 50^{\prime} \mathrm{N}$ & $\begin{array}{l}\text { Patches, low sulfide } \\
\text { mounds, cracks, } \\
\text { collapse features }\end{array}$ & 10 & 0.04 & $\begin{array}{l}7 \text { sites } \\
5 \times 5 \\
\text { each }\end{array}$ & $\begin{array}{c}40.7 \times 7= \\
285\end{array}$ & 0.9 & $\begin{array}{l}\text { Ramondenc et al. } \\
\text { (2006); } \\
\text { Shank et al. (1998) }\end{array}$ & $\begin{array}{l}\text { Von Damm and } \\
\text { Lilley (2004) }\end{array}$ \\
\hline $21^{\circ} \mathrm{N}$ & & 20 & 0.1 & $\begin{array}{c}80 \text { to } \\
700\end{array}$ & 11 to 900 & & $\begin{array}{l}\text { Converse et al. } \\
\text { (1984) }\end{array}$ & \\
\hline \multicolumn{9}{|c|}{ Galápagos Spreading Center (GSC) } \\
\hline $\begin{array}{l}\text { Rose } \\
\text { Garden, } \\
86^{\circ} \mathrm{W}\end{array}$ & $\begin{array}{l}\text { Cracks between } \\
\text { pillows and talus } \\
\text { blocks }\end{array}$ & 10.5 & 2 to $10 \mathrm{~L} \mathrm{~s}^{-1}$ & & & & $\begin{array}{l}\text { Corliss et al. } \\
\text { (1979) }\end{array}$ & $\begin{array}{l}\text { Edmond et al. } \\
\qquad(1979)\end{array}$ \\
\hline
\end{tabular}

${ }^{1}$ Heat flux values refer to the area over which they are measured. If no area is given, the heat output refers to the entire vent field. 


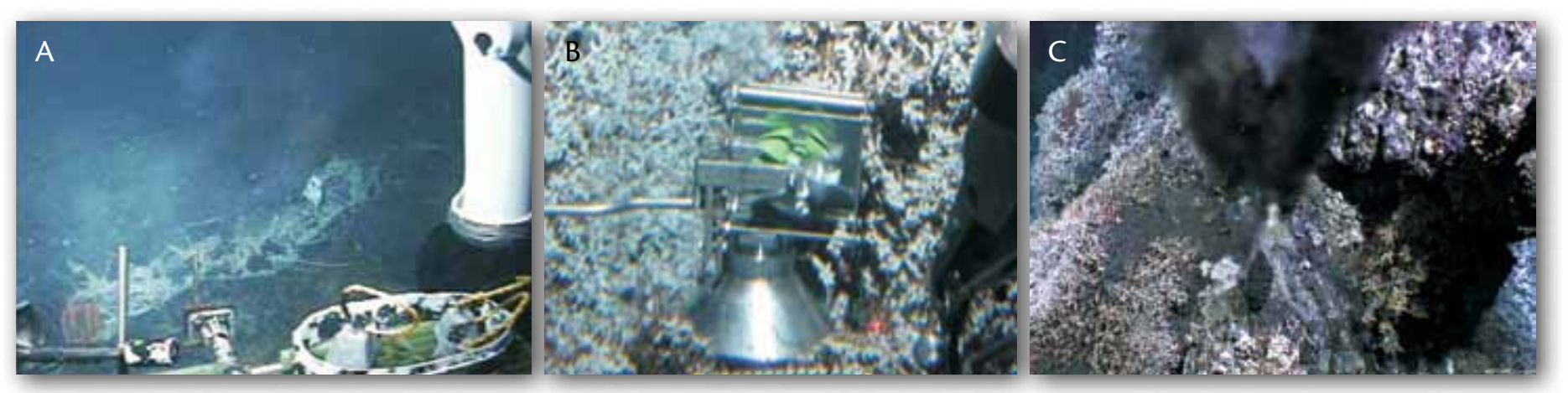

Figure 1. (A) Photo taken on Jason dive J1-286 of diffuse flow emanating as faint smoke from a crack with some biota present; crack is located north of S\&M vent in the Main Endeavour Field, Juan de Fuca Ridge. Courtesy of Paul Johnson, Woods Hole Oceanographic Institution (WHOI) and the National Science Foundation (NSF) (B) Deployment of the cup anemometers over low-temperature diffuse flow site covered with tubeworms on Alvin dive 4412 at a low-temperature vent field (ClamBed) at Endeavour Segment. The diffuse flow corresponds to the cloudy area appearing to the left of and just above the flow meter. Courtesy of Leonid Germanovich, Raymond Lee, WHOI, and NSF (C) Photo of diffuse flow from just below a black smoker on the side of a sulfide structure (part of Grotto Vent in the Main Endeavour Field). Courtesy of CSSF/NEPTUNE Canada

breccias (Humphris et al., 2002; Ondeas et al., 2009), collapse pits (Goto et al., 2003), lava rubble (Butterfield et al., 2004), and sulfide mineral deposit rubble (Tivey, 2007). The common association of fluid discharge with major crustal faults (Curewitz and Karson, 1997) or fissures in an axial summit trough (Fornari et al., 2004) has been noted previously. Low-temperature fluids also vent from a variety of structures that seem discrete or focused such as flow emitted from lava pillars (Goto et al., 2003; Butterfield et al., 2004). Additionally, "diffuser" chimneys called beehives emit low-temperature fluids at low flow rates (Tivey, 1995). Macrofauna communities often obscure the geologic details (Figure 1B). Scheirer et al. (2006) point out that biota may extend beyond the bounds of outflow because tidally driven ocean bottom currents can transport the nutrient-rich fluid output laterally over a larger region.

\section{MAPPING THE DISTRIBUTION OF DIFFUSE FLOW}

During seafloor surveys, diffuse flow is usually recognized visually as shimmering water, where, much like the wavering above an asphalt road surface on a hot day, the rapid thermal fluctuations of the diffuse fluids distort the seafloor surface beneath them. Additionally, diffuse-flow locations have been recognized by the occurrence of biota. The measurement of temperature anomalies generally only follows the inference of diffuse flow. However, shimmering water implies only that there is heat, not that the fluid came from the subsurface. Therefore, interpretations of the presence of shimmering waterwhether heated through subsurface mixing with hot water or conductionnear black smokers may be ambiguous.

The distribution of diffuse flow varies from very localized around hightemperature chimneys (Tivey et al., 2002), to "patchy" (Ramondenc at al., 2006), to ubiquitous (Corliss et al., 1979; Ondeas et al., 2009). Overall, the distributions and styles of diffuse venting seem to vary as much within individual vent fields as between them (Tivey et al., 2002; Ramondenc at al., 2006; Ondeas et al., 2009). Except

Karen Bemis (bemis@rci.rutgers.edu) is Research Associate, Institute of Marine and Coastal Sciences, Rutgers University, New Brunswick, NJ, USA. Robert P. Lowell is Research Professor, Department of Geosciences, Virginia Tech, Blacksburg, VA, USA. Aida Farough is PhD Candidate, Department of Geosciences, Virginia Tech, Blacksburg, VA, USA. possibly for mid-ocean ridges that are largely or completely buried by sediment (e.g., Middle Valley on the Juan de Fuca Ridge), fluid flow even in the shallow subsurface is likely to be controlled by permeable crack distributions (Curewitz and Karson, 1997; Fontaine and Wilcock, 2006). The patchy distribution of diffuse flow over kilometer-scale areas suggests that high-temperature upflow at depth induces convection in the shallow crust, with the result that some hightemperature fluid focuses and exits through a few larger cracks while the remaining high-temperature fluid mixes with circulating seawater and exits the seafloor via an irregularly distributed crack network (Ramondenc et al., 2008; Germanovich et al., 2011). The depth to which broadly distributed fluids circulate and mix with high-temperature fluids is unknown, but it might be inferred either from geochemical data (discussed below) or determined directly by measuring subsurface temperatures through drill holes. Geophysical observations, such as 
microearthquake distributions and properties (Wilcock et al., 2002; Tolstoy et al., 2008), can constrain the width and depth of circulating fluids (although not the presence of high-temperature fluids).

\section{NEW TOOLS FOR FLOW OR}

\section{FLUX MEASUREMENT}

The direct measurement of diffuse fluid heat flux requires three pieces of knowledge: the temperature of the fluid, the rate of fluid flow, and the area over which that rate pertains. Of these parameters, temperature is relatively easy to measure but difficult to integrate over an area because of its variability. Flow rates are even more difficult to measure given deep-ocean turbulence and currents, which affect many standard measurement techniques.

Several studies have used submersibles or remotely operated vehicles to systematically videotape a region and map the distribution of biota living in or near diffuse flow (Delaney et al., 1992; Shank et al., 1998; Von Damm and Lilley, 2004), although these observations do not result in a quantitative estimate of diffuse-flow area. Recently, a sonar-based remote-sensing technique was developed to detect the acoustic equivalent of the visible shimmering of the diffuse flow (Rona and Light, 2011; Di Iorio et al., 2012, in this issue); for example, diffuse flow was inferred from acoustic shimmering (called decorrelation) on the north flank of Grotto vent (Figure 2; Rona and Light, 2011). Like optical

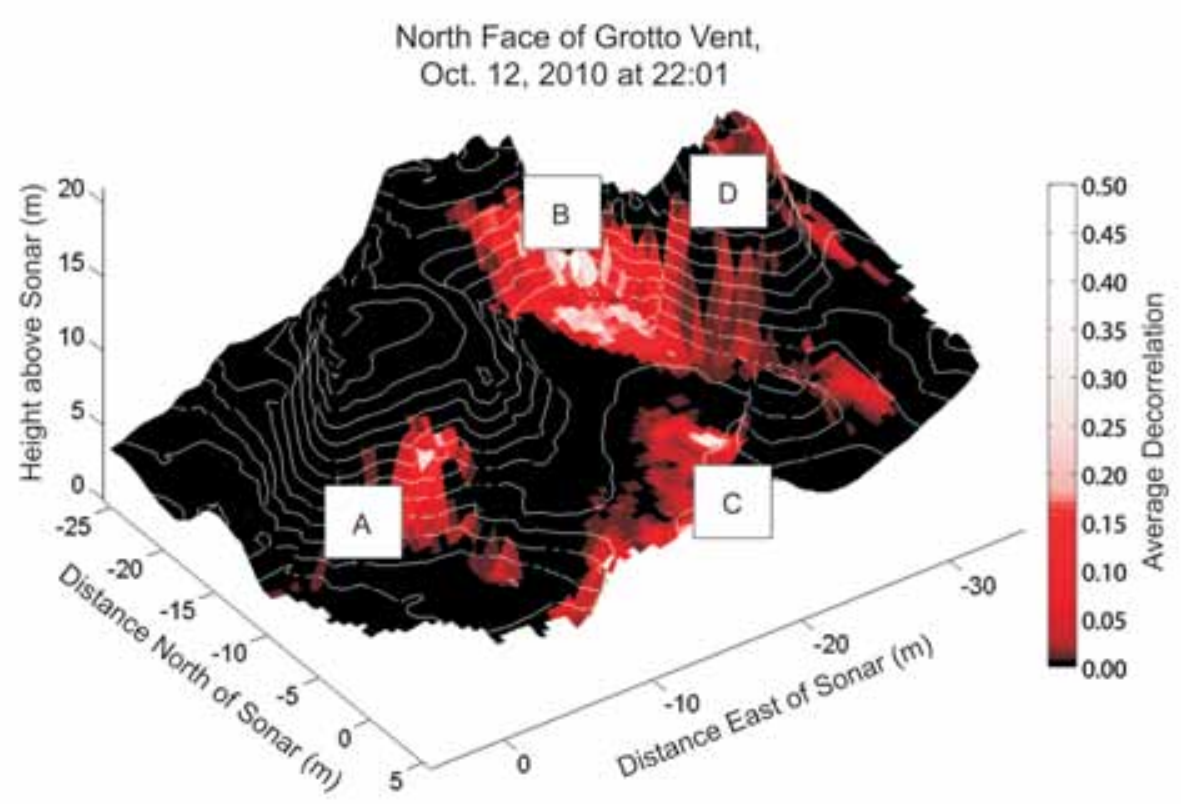

Figure 2. The sonar platform COVIS (Cabled Observatory Vent Imaging System) can detect the turbulent fluctuations associated with shimmering (warm) water as a decorrelation of the sonar signal (Figure 3 in Di lorio, 2012, in this issue, describes more of the mechanism for diffuse-flow mapping). The turbulent fluctuations (observed areas indicated by letters in squares on the map) could be associated with several different phenomena including the following: (1) low-temperature outflow through biotic assemblages or sulfide structures as in Figure 1b,c (diffuse flow has been verified at sites $A$ and $B$ ); (2) seawater heated by conduction through the sulfide edifice (conductive heating could occur at site D beneath the vigorous black smokers on Grotto's North Tower); (3) passage of the acoustic ray through a black smoker plume (which is unlikely with the current placement of COVIS); (4) low-temperature flow through cracks in the seafloor as in Figure 1a (which is unverified, but possible, for site C).

shimmering, acoustic shimmering also cannot determine the heat source of this diffuse flow (i.e., magmatic versus conductive). Systematic surveys, especially collection of collocated chemical measurements, are needed to determine the amount of high-temperature or deep-circulation fluids present and the relationships between diffuse fluids and temperature, flow rate, and acoustic decorrelation.

A variety of tools to measure either vertical flow rates or volume fluxes have been developed in the past decade. Methods of estimating the subsurface flow involve concentrating the flow from an area (Schultz et al., 1992; Pruis and Johnson, 2004; Ramondenc et al., 2006; Germanovich et al., 2009; Sarrazin et al., 2009), resolving the two- or threedimensional velocity field (Mittelstaedt et al., 2010), or modeling how fluids rising from diffuse flow sites are diluted (Trivett and Williams, 1994; Goto et al., 2003). Few new instruments have been used at the same sites, so comparisons of results are difficult.

An early version of a flux concentration device used an electromagnetic flowmeter to estimate vertical velocity, temperature gradients, and heat flux at several Endeavour Segment sites on the Juan de Fuca Ridge (Schultz et al., 1992). Pruis and Johnson (2004) developed a larger instrument, which is cemented to the seafloor to provide a hydrologic seal, to measure flow from $1 \mathrm{~m}^{2}$ areas at Axial Volcano sites on Juan de Fuca Ridge. Ramondenc et al. (2006) used a combination of a steel plate bottom with $1.3 \mathrm{~cm}$ hole and a $10 \mathrm{~cm}$ tall wall as a backdrop to image eddies flowing past and estimate vertical velocity for both focused and diffuse flows at several sites at 950'N EPR. Sarrazin et al. (2009) 
combined flow visualization, in which individual particles are tracked passing through a transparent tube, with a duothermistor flow sensor mounted inside the tube, which is sealed to the seafloor by a weighted flexible skirt. In a test at the Lucky Strike hydrothermal vents near $37^{\circ} \mathrm{N}$ on the Mid-Atlantic Ridge, the video and sensor flow rates generally agreed. Germanovich et al. (2009) also used video imaging to estimate the angular velocity of a cup anemometer mounted above a cylindrical flow concentrator (Figure 1B) and thus obtained flow rates at several Endeavour Segment diffuse-flow sites. This device and more recently developed turbine flowmeters work for both focused and diffuse flow sites (Di Iorio et al., 2012, in this issue).

A different approach uses a singlepoint mounting system with three thermistors spaced vertically and three mutually perpendicular modular acoustic velocity sensors (MAVs) just above the seafloor to determine the temporal variability of horizontal velocity, vertical velocity, dissipation rate, and heat flux at several Endeavour diffuse-flow sites (Pruis, 2004). Pruis (2004) used a simple $1 \mathrm{~m}$ diameter triangular array of thermistors to determine spatial variability. Alternatively, Mittelstaedt et al. (2010) applied particle image velocimetry to video image sequences to estimate the two-dimensional velocity field based on the distortions of small-scale background features at sites at Lucky Strike. All of these different tools have increased our knowledge of diffuse fluxes and also increased the potential for more systematic surveys of diffuse-flow spatial variations.
PARTITIONING BETWEEN

\section{FOCUSED AND DIFFUSE}

\section{HEAT OUTPUT}

The relationship between high-temperature focused and low-temperature diffuse-flow venting provides an important key to understanding hydrothermal systems at oceanic spreading centers. Current heat-output data from various vent fields suggest that the fraction of heat output attributed to diffuse flow may range between 50 and $90 \%$ of the total (Rona and Trivett, 1992; Schultz et al., 1992; Baker et al., 1993; Ramondenc et al., 2006; Veirs et al., 2006). The relationship between diffuse and focused flows at the vent-field scale at oceanic spreading centers can be clarified further for hydrothermal systems for which there are estimates of the partitioning between focused and diffuse heat output, as well as temperature and geochemical data for both high- and low-temperature venting. At present, these data are available for the East Pacific Rise at 9 ${ }^{\circ} 50^{\prime} \mathrm{N}$ (Lowell et al., 2012, in this issue), for the Main Endeavour Field (MEF) on the Juan de Fuca Ridge (Kelley et al., 2002; Lang et al., 2006), and for the ASHES hydrothermal field at Axial Volcano on the Juan de Fuca Ridge (Rona and Trivett, 1992; Lang et al., 2006).

Figure 3 shows a two-limb singlepass hydrothermal model representing:

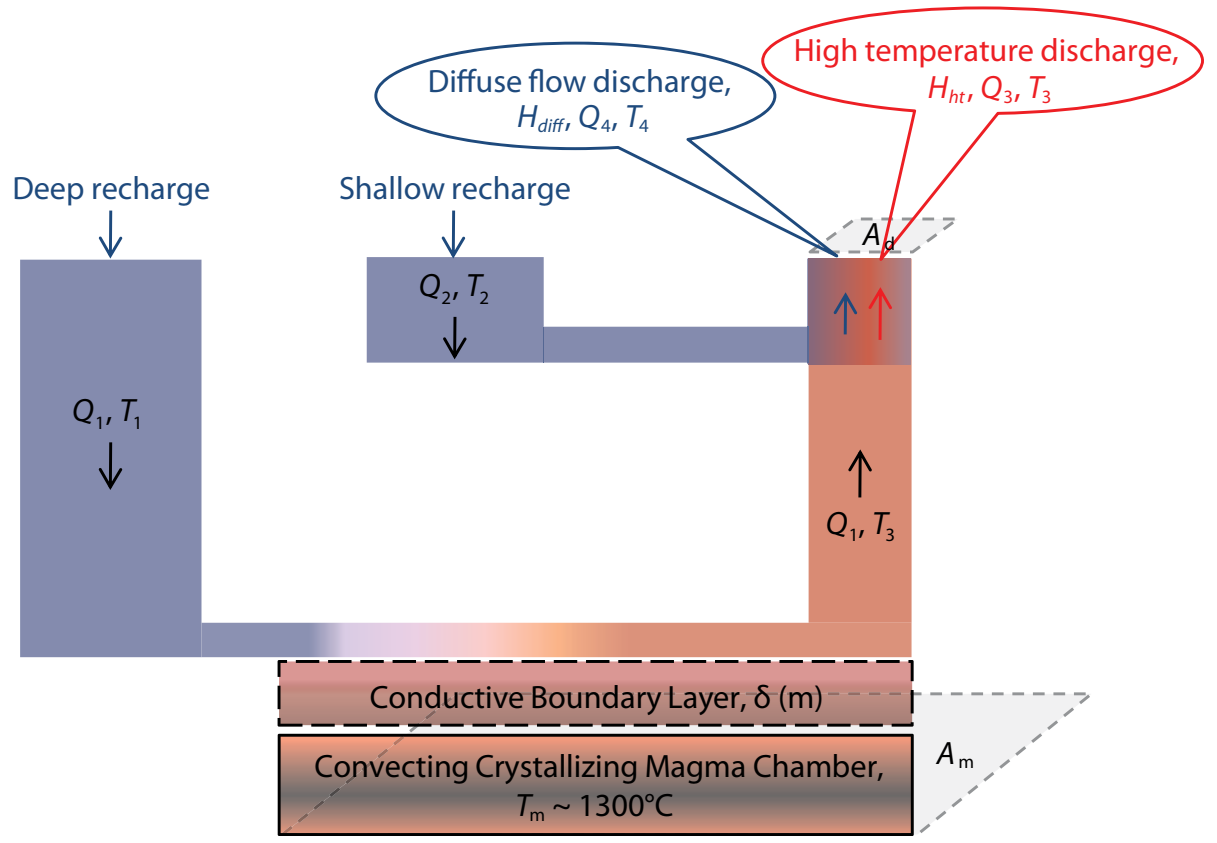

Figure 3. Schematic of a cross section of a two-limb, single-pass hydrothermal circulation model for understanding the partitioning between focused and diffuse flows at the vent-field scale (modified from Lowell et al., 2012, in this issue). Seawater enters through deep recharge with a relatively low temperature of $T_{1}$ and a mass flux of $Q_{1}$. As it gets closer to the top of the magma chamber, the seawater's temperature increases and it reacts with the surrounding rock that is hot as a result of heat conduction through the boundary layer from a convecting, crystallizing magma chamber. The buoyant fluid then rises to the discharge zone with the same mass flux $Q_{1}$ and a higher temperature $T_{3}$. Some portion of the hightemperature hydrothermal fluid mixes with seawater at temperature $T_{2}$ and mass flux $Q_{2}$ that has circulated in a shallow zone. As a result of the mixing, the low-temperature fluid is discharged diffusely at the seafloor, with heat output $H_{\text {diff }}$, mass flux $Q_{4}$, and temperature $T_{4}$. The remainder of the high-temperature fluid discharges at the seafloor with heat output $H_{h t}$, mass flux $Q_{3}$, and temperature $T_{3}$. $A_{m}$ is the crosssectional area of the magma chamber through which heat is transferred, and $A_{d}$ is the cross-sectional area of the discharge zone. 
(1) a deep circulation limb with a mass flow rate $Q_{1}$ that is heated by the subaxial magma chamber and results in a hightemperature fluid $T_{3}$, and (2) a shallow circulation limb, likely residing in seismic Layer 2A (uppermost part of the oceanic crust) with a mass flux $Q_{2}$ and temperature $T_{2}$ that mixes with some of the ascending high-temperature fluid, resulting in diffuse heat output $H_{\text {diff }}=c_{\text {diff }} Q_{4} T_{4}$. The remainder of the high-temperature heat output is given by $H_{h t}=c_{h t} Q_{3} T_{3}$. The specific heat of the fluid is given by $c_{d i f f}$ and $c_{h t}$ for lowtemperature and high-temperature fluid, respectively. By knowing the individual heat outputs $H_{d i f f}$ and $H_{h t}$ at the vent-field scale, together with their mean temperatures $T_{3}$ and $T_{4}$, the mass flows $Q_{3}$ and $Q_{4}$, respectively, can be calculated. To obtain the flows $Q_{1}$ and $Q_{2}$, we use the mass balance expression

$Q_{4}=Q_{2}+Q_{1}-Q_{3}$

and the expression for the mixing ratio between diffuse and high-temperature fluids derived from the concentrations of a conservative geochemical tracer such as $\mathrm{Mg}$ or $\mathrm{Si}$ in the vent fluid

$\xi=\frac{\chi_{d i f f}-\chi_{s w}}{\chi_{h t}-\chi_{s w}}$ where $\chi$ is the chemical concentration of the tracer and the subscripts diff, $h t$, and $s w$ refer to diffuse, high-temperature, and seawater concentrations, respectively. In terms of mass flux, $\xi=\left(Q_{1}-Q_{3}\right) / Q_{4}$, so the deep-seated high-temperature mass flow $Q_{1}$ can be determined from the focused and diffuse heat outputs and the geochemical data; then, $Q_{2}$ can be determined from Equation 1.

Lowell et al. (2012, in this issue) describe the observational data and partitioning results for $9^{\circ} 50^{\prime} \mathrm{N}$ EPR using $\mathrm{Mg}$ as a conservative tracer. Table 2 shows these results and additional similar model results for MEF and ASHES. An important feature of these results is that approximately $90 \%$ of the heat output from these vent fields ultimately stems from high-temperature fluid circulating to near the top of the subaxial magma chamber, whereas a significant fraction of the total heat output appears as diffuse flow. This output result can be seen by comparing the value of $Q_{1}$ determined from the partitioning data with the value $Q_{1^{\star}}$, which is the value of high-temperature mass flux determined by assuming that all the heat output resulted from hightemperature flow (Farough, 2011).

\section{GEOCHEMICAL FLUXES}

Geochemical fluxes from seafloor hydrothermal systems and the use of chemical compounds by biota are of considerable interest. For example, Crowell et al. (2008) show that $\mathrm{H}_{2} \mathrm{~S}$ is removed from diffuse-flow vents on the EPR near $9^{\circ} 50^{\prime} \mathrm{N}$ by a combination of pyrite precipitation and biological activity. A detailed analysis of geochemical fluxes is beyond the scope of this paper, but we provide two examples of how heat-flow partitioning data can be used to estimate the relative geochemical fluxes of focused and diffuse discharge on the vent-field scale. Geochemical flux estimates at this scale are different from those of Lang et al. (2006), who estimated the flux of dissolved organic carbon (DOC) on the global scale, and also different from those of Wankel et al. (2011), who determined geochemical fluxes of $\mathrm{CH}_{4}, \mathrm{CO}_{2}$, and $\mathrm{H}_{2}$ from measurements of chemical concentration and flow rate at specific discharge sites.

For example, Lang et al. (2006) find that the average DOC concentration in focused and diffuse vent sites on the MEF are $15 \mu \mathrm{M}$ and $47 \mu \mathrm{M}$, respectively. Using the values $Q_{3}$ and $Q_{4}$ from Table 2 to represent the focused

Table 2. Heat-flow partitioning at the vent-field scale.

\begin{tabular}{|c|c|c|c|c|c|c|c|c|c|c|c|c|}
\hline Site & \multicolumn{3}{|c|}{ Diffuse-Flow Data } & \multicolumn{3}{|c|}{ High-Temperature Data } & \multicolumn{6}{|c|}{ Results } \\
\hline EPR & $140^{1}$ & $30^{2}$ & $49.2^{2}$ & $20^{1}$ & $370^{2}$ & 0 & 78 & 1,103 & 11 & 1,170 & 0.057 & 86 \\
\hline
\end{tabular}

${ }^{1}$ Ramondenc et al., 2006. ${ }^{2}$ Von Damm and Lilley, 2004. ${ }^{3}$ Veirs et al., 2006. ${ }^{4}$ Lang et al., 2006. ${ }^{5}$ Kelley et al., 2002. ${ }^{6}$ Rona and Trivett, $1992 .{ }^{7}$ The value $Q_{1 *}$ represents the mass flux from the vent field if all the heat output were at high temperature.

EPR = East Pacific Rise, MEF = Main Endeavour Field, ASHES = Axial Seamount Hydrothermal Emissions Study vent field NOTE: sW Mg $=53 \mathrm{mmol}$ at MEF and $\mathrm{ASHES}^{4}$, and $52.2 \mathrm{mmol}$ at EPR ${ }^{2}$, respectively. 
and diffuse mass flux from the MEF, and assuming the density of hightemperature fluid to be $700 \mathrm{~kg} \mathrm{~m}^{-3}$, we obtain DOC flux $F_{D O C}=2.6 \mathrm{mmol} \mathrm{s}^{-1}$ from high-temperature vents, and $F_{D O C}=55 \mathrm{mmol} \mathrm{s}^{-1}$ from diffuse vents, which is $\sim 20$ times greater than from high-temperature vents.

Similarly, the mean concentration of Fe in high- and low-temperature vents near Bio 9 and Bio 9', and $P$ vents at EPR 9 ${ }^{\circ} 50^{\prime} \mathrm{N}$ between 1991 and 2000 is 3,200 $\mathrm{mmol}$ and $113 \mathrm{mmol}$, respectively (Von Damm and Lilley, 2004). Using the values of $Q_{3}$ and $Q_{4}$ from Table 2 to represent the focused and diffuse mass flux from EPR $9^{\circ} 50^{\prime} \mathrm{N}$, we obtain $F_{F e}=35 \mathrm{mmol} \mathrm{s}^{-1}$ from high-temperature vents and $F_{F e}=132 \mathrm{mmol} \mathrm{s}^{-1}$ from diffuse-flow vents, respectively. Thus, the flux of Fe from diffuse flow sites at EPR $9^{\circ} 50^{\prime} \mathrm{N}$ is nearly four times that from high-temperature vents.

\section{MODELING DIFFUSE FLOW}

The complexity in style and distribution of diffuse venting at oceanic spreading centers, coupled with the limited constraining data on flow rate, has hindered the development of quantitative models. Because geochemical data generally show that diffuse flow is a mixture of black smoker fluid and seawater (Table 2), models must reflect this mixing. The treatment of this mixing in models strongly affects the subsurface temperature regime, and because the microbial biosphere is limited to temperatures $\leq \sim 120^{\circ} \mathrm{C}$, different mixing models yield different estimates for the extent of the subsurface microbial biosphere at mid-ocean ridges. For example, one approach is to consider constant, steady-state upflow of black smoker fluid and impose a linear heat transfer boundary condition at the seafloor in conjunction with observed diffuse-flow velocities, which results in high-temperature fluid within millimeters to centimeters beneath the seafloor (Craft et al., 2008). This result, though surprising, is not entirely unrealistic, as temperatures approaching $100^{\circ} \mathrm{C}$ have been observed a few centimeters below the seafloor (Rona et al., 1990).

Another approach considers diffuse flow induced by high-temperature focused discharge. In this case, steadystate boundary layer methods have been used to model low-temperature fluid flow adjacent to a hot wall at constant temperature in order to estimate the rate of production of biological floc and the reduction of porosity resulting from microbial growth (Crowell et al., 2008), and to investigate heat-flux partitioning (Craft et al., 2009). In these models, biological activity could occur several hundred meters below the seafloor. The boundary layer results are similar to those obtained using numerical models of convection in the presence of a highpermeability Layer 2A. In these models, high-temperature plumes venting at the surface induce convection within Layer 2A, resulting in narrow recharge zones adjacent to high-temperature plumes (Lowell et al., 2007; Coumou et al., 2008). The implied distribution pattern for discharge corresponds consistently with the patchy distribution of diffuse flow observed (Figure 2).

\section{CONCLUSIONS}

In this paper, we reviewed the variability of diffuse-flow venting styles, ranging from visible flow directly out of cracks, to flow through macrofauna assemblages, to flow over broad areas of high porosity such as sulfide mounds or fractured lava fields. All temperatures measured were highly variable in time and space. New developments in tools for measuring flow and flux rates are starting to capture the variations in flow rates. Estimates for the partitioning of high-temperature fluids between focused and diffuse vents were calculated from physical (temperature and heat flux) and geochemical (tracer concentration) observations, indicating that a significant fraction of the total heat output was through diffuse flow.

A review of current models of subsurface circulation suggests that subsurface temperature distribution may be highly variable. In some cases, simple onedimensional models predict relatively high fluid temperatures $\left(100^{\circ} \mathrm{C}\right)$ just below the seafloor. Other mixing models suggest patchy distributions of diffuse flow, reflecting shallow subsurface convection and mixing with ascending high-temperature fluids to depths of hundreds of meters beneath the seafloor.

While great progress has been made in the last decade, partitioning estimates and model prediction are still based on spot estimates extrapolated over a significantly larger area. There is a critical need for systematic measurements and long-term monitoring to quantitatively capture the spatial and temporal variability and to understand its causes. To this end, all observations should include multiple types of measurement (e.g., temperature, flow rate, area of venting, fluid chemistry). Our understanding of the partitioning of chemical and heat fluxes is still limited, as is our understanding of microbial utilization of these fluxes. As the observations improve, they will justify the development of more robust mathematical models. 


\section{ACKNOWLEDGEMENTS}

We thank the guest editor Jim Holden and two anonymous reviewers for their helpful comments on previous versions of this manuscript. This work stemmed from interactions of the "Spatial and Temporal Variation in Chemistry and Heat Fluxes in Hydrothermal Systems, Including Chronic Plumes” Working Group of the 2010 R2K Community Meeting that met in Portland, OR, in October 2010. This meeting was supported by NSF grant OCE-0838923. This research was also supported in part by NSF grant 0926418 to RPL. The COVIS project (and KGB in part) was supported by NSF grants OCE 0824612 and OCE 0825088 and thanks CSSF/NEPTUNE Canada for a successful installation.

\section{REFERENCES}

Baker, E.T., G.J. Massoth, S.L. Walker, and R.W. Embley. 1993. A method for quantitatively estimating diffuse and discrete hydrothermal discharge. Earth and Planetary Science Letters 118:235-249, http:// dx.doi.org/10.1016/0012-821X(93)90170-E.

Butterfield, D.A., G.J. Massoth, R.E. McDuff, J.E. Lupton, and M.D. Lilley. 1990. Geochemistry of hydrothermal fluids from Axial Seamount Hydrothermal Emissions Study Vent Field, Juan de Fuca Ridge: Subseafloor boiling and subsequent fluidrock interaction. Journal of Geophysical Research 95:12,895-12,921, http://dx.doi.org/ 10.1029/JB095iB08p12895.

Butterfield, D.A., K.K. Roe, M.D. Lilley, J.A. Huber, J.A. Baross, R.W. Embley, and G.J. Massoth. 2004. Mixing, reaction and microbial activity in the sub-seafloor revealed by temporal and spatial variation in diffuse flow vents at Axial Volcano. Pp. 269-289 in The Subseafloor Biosphere at Mid-Ocean Ridges. W.S.D. Wilcock, E.F. DeLong, D.S. Kelley, J.A. Baross, and S.C. Cary, eds, Geophysical Monograph Series, vol. 144, American Geophysical Union, Washington, DC.

Cooper, M.J., H. Elderfield, and A. Schultz. 2000. Diffuse hydrothermal fluids from Lucky Strike hydrothermal vent field: Evidence for a shallow conductively heated system. Journal of Geophysical Research 105:19,369-19,375, http:// dx.doi.org/10.1029/2000JB900138.
Converse, D.R., H.D. Holland, and J.M. Edmond. 1984. Flow rates in the axial hot springs of the East Pacific Rise $\left(21^{\circ} \mathrm{N}\right)$ : Implications for the heat budget and the formation of massive sulfide deposits. Earth and Planetary Science Letters 69: 159-175, http://dx.doi.org/ 10.1016/0012-821X(84)90080-3.

Corliss, J.B., J. Dymond, L.I. Gordon, J.M. Edmond, R.P. von Herzen, R.D. Ballard, K. Green, D. Williams, A. Bainbridge, K. Crane, and T.H. van Andel. 1979. Submarine thermal springs on the Galápagos Rift. Science 203:1,073-1,082, http://dx.doi.org/ 10.1126/science.203.4385.1073.

Coumou, D., T. Driesner, and C. Heinrich. 2008. The structure and dynamics of mid-ocean ridge hydrothermal systems. Science 321:1,825-1,828, http://dx.doi.org/10.1126/science.1159582.

Craft, K., and R.P. Lowell. 2009. A boundary layer model for submarine hydrothermal flows at on-axis and near-axis locations. Geochemistry Geophysics Geosystems 10, Q12012, http:// dx.doi.org/10.1029/2009GC002707.

Craft, K., R.P. Lowell, and L.N. Germanovich. 2008. Models of diffuse flow near mid-ocean ridge axes. Eos, Transactions, American Geophysical Union 89(53):Fall Meeting Supplement Abstract V41B-2073.

Crowell, B.W., R.P. Lowell, and K.L. Von Damm. 2008. A model for the production of sulfur floc and "snowblower" events at mid-ocean ridges. Geochemistry Geophysics Geosystems 9, Q10T02, http://dx.doi.org/10.1029/2008GC002103.

Curewitz, D., and J.A. Karson. 1997. Structural settings of hydrothermal outflow: Fracture permeability maintained by fault propagation and interaction. Journal of Volcanology and Geothermal Research 79:149-168.

Delaney, J.R., V. Robigou, R.E. McDuff, and M.K. Tivey. 1992. Geology of a vigorous hydrothermal system on the Endeavour Segment, Juan de Fuca Ridge. Journal of Geophysical Research 97:19,663-19,682, http://dx.doi.org/ 10.1029/92JB00174.

Di Iorio, D., J.W. Lavelle, P.A. Rona, K. Bemis, G. Xu, L.N. Germanovich, R.P. Lowell, and G. Genc. 2012. Measurements and models of heat flux and plumes from hydrothermal discharges near the deep seafloor. Oceanography 25(1):168-179, http:// dx.doi.org/10.5670/oceanog.2012.14.

Edmond, J.M., C. Measures, R.E. McDuff, L.H. Chan, R. Collier, B. Grant, L.I. Gordon, and J.B. Corliss. 1979. Ridge crest hydrothermal activity and the balances of the major and minor elements in the ocean: The Galapagos data. Earth and Planetary Science Letters 46:1-18, http://dx.doi.org/10.1016/ 0012-821X(79)90061-X.

Farough, A. 2011. A parameterized approach to partitioning between focused and diffuse heat output and modeling hydrothermal recharge at the East Pacific Rise $9^{\circ} 50^{\prime}$ N. M.S. Thesis, Virginia Tech, Blacksburg, VA, 79 pp.
Fontaine, F.J., and W.S.D. Wilcock. 2006. Dynamics and storage of brine in mid-ocean ridge hydrothermal systems. Journal of Geophysical Research 111, B06102, http://dx.doi.org/ 10.1029/2005JB003866.

Fornari, D.J., M. Tivey, H. Schouten, M. Perfit, D. Yoerger, A. Bradley, M. Edwards, R. Haymon, D. Scheirer, K. Von Damm, and others. 2004. Submarine lava flow emplacement at the East Pacific Rise $9^{\circ} \mathrm{N}$ : Implications for uppermost ocean crust stratigraphy and hydrothermal fluid circulation. Pp. 187-217 in Mid-Ocean Ridges: Hydrothermal Interactions Between the Lithosphere and Oceans. C.R. German, J. Lin, and L.M. Parson, eds, Geophysical Monograph Series, vol. 148, American Geophysical Union, Washington, DC.

Foustoukos, D.I., N.J. Pester, K. Ding, and W.E. Seyfried Jr. 2009. Dissolved carbon species in associated diffuse and focused flow hydrothermal vents at the Main Endeavour Field, Juan de Fuca Ridge: Phase equilibria and kinetic constraints. Geochemistry Geophysics Geosystems 10, Q10003, http://dx.doi.org/ 10.1029/2009GC002472.

Germanovich, L.N., D. Di Iorio, G. Genc, R.S. Hurt, R.P. Lowell, J.F. Holden, D.A. Butterfield, and E.J. Olson. 2009. Direct measurements of hydrothermal heat output at Juan de Fuca Ridge. Eos, Transactions, American Geophysical Union 90(52):Fall Meeting Supplement Abstract OS13A-1179.

Germanovich, L.N., R.P. Lowell, and P. Ramondenc. 2011. Magmatic origin of hydrothermal response to earthquake swarms: Constraints from heat flow and geochemical data. Journal of Geophysical Research 116, B05103, http://dx.doi.org/ 10.1029/2009JB006588.

Goto, S., T. Gamo, H. Chiba, K. Fujioka, and K. Mitsuzawa. 2007. Contribution of heat outputs from high- and low-temperature hydrothermal sources to the neutrally buoyant plume at the TAG hydrothermal mound, Mid-Atlantic Ridge. Earth, Planets and Space 59:1,141-1,146.

Goto, S., M. Kinoshita, and K. Mitsuzawa. 2003. Heat flux estimate of warm water flow in a low-temperature diffuse flow site, southern East Pacific Rise $17^{\circ} 25^{\prime}$ S. Marine Geophysical Research 24:345-357, http://dx.doi.org/10.1007/ s11001-004-3957-x.

Holland, M.E., J.A. Baross, and J.F. Holden. 2004. Illuminating subseafloor ecosystems using microbial tracers. Pp. 291-303 in The Subseafloor Biosphere at Mid-Ocean Ridges. W.S.D. Wilcock, E.F. DeLong, D.S. Kelley, J.A. Baross, and S.C. Cary, eds, Geophysical Monograph Series, vol. 144, American Geophysical Union, Washington, DC.

Humphris, S.E., D.J. Fornari, D.S. Scheirer, C.R. German, and L.M. Parson. 2002. Geotectonic setting of hydrothermal activity on the summit of Lucky Strike Seamount $\left(37^{\circ} 17^{\prime} \mathrm{N}\right.$, 
Mid-Atlantic Ridge). Geochemistry Geophysics Geosystems 3(8), 1049, http://dx.doi.org/ 10.1029/2001GC000284.

Kelley, D.S., J.A. Baross, and J.R. Delaney. 2002. Volcanoes, fluids, and life at mid-oceanic ridge spreading centers. Annual Review of Earth and Planetary Sciences 30:385-491, http://dx.doi. org/10.1146/annurev.earth.30.091201.141331.

Lang, S.Q., D.A. Butterfield, M.D. Lilley, H.P. Johnson, and J.I. Hedges. 2006. Dissolved organic carbon in ridge-axis and ridgeflank hydrothermal systems. Geochimica Cosmochimica Acta 70:3,830-3,842, http:// dx.doi.org/10.1016/j.gca.2006.04.031.

Lowell, R.P., B.W. Crowell, K.C. Lewis, and L. Liu. 2008. Modeling multiphase, multicomponent processes at oceanic spreading centers. Pp. 15-44 in Magma to Microbe: Modeling Hydrothermal Processes at Ocean Spreading Centers. R.P. Lowell, J.S. Seewald, A. Metaxas, and M.R. Perfit, eds, Geophysical Monograph Series, vol. 178, American Geophysical Union, Washington, DC.

Lowell, R.P., A. Farough, L.N. Germanovich, L.B. Hebert, and R. Horne. 2012. A ventfield-scale model of the East Pacific Rise $9^{\circ} 50^{\prime} \mathrm{N}$ magma-hydrothermal system. Oceanography 25(1):158-167, http:// dx.doi.org/10.5670/oceanog.2012.13.

Lowell, R.P., S.R. Gosnell, and Y. Yang. 2007. Numerical simulations of single-pass hydrothermal convection at mid-ocean ridges: Effects of the extrusive layer and temperature dependent permeability. Geochemistry Geophysics Geosystems 8, Q10011, http://dx.doi. org/10.1029/2007GC001653.

Mittelstaedt, E., A. Davaille, P.E. van Kaken, N. Gracias, and J. Escartín. 2010. A noninvasive method for measuring the velocity of diffuse hydrothermal flow by tracking moving refractive index anomalies. Geochemistry Geophysics Geosystems 11, Q10005, http://dx.doi.org/ 10.1029/2010GC003227.

Ondeas, H., M. Cannat, Y. Fouquet, A. Normand, P.M. Sarradin, and J. Sarrazin. 2009. Recent volcanic events and the distribution of hydrothermal venting at the Lucky Strike hydrothermal field, Mid-Atlantic Ridge. Geochemistry Geophysics Geosystems 10, Q02006, http:// dx.doi.org/10.1029/2008GC002171.

Pruis, M. 2004. Energy and volume flux into the deep ocean: Examining diffuse hydrothermal systems. PhD Thesis, University of Washington.

Pruis, M.J., and H.P. Johnson. 2004. Tapping into the sub-seafloor: examining diffuse flow and temperature from an active seamount on the Juan de Fuca Ridge. Earth and Planetary Science Letters 217:379-388, http://dx.doi.org/10.1016/ S0012-821X(03)00607-1.

Ramondenc, P., L.N. Germanovich, and R.P. Lowell. 2008. Modeling the hydrothermal response to earthquakes at oceanic spreading centers. Pp. 97-121 in Magma to Microbe: Modeling Hydrothermal Processes at Oceanic Spreading Centers. R.P. Lowell, J.S. Seewald,
A. Metaxas, and M.R. Perfit, eds, Geophysical Monograph Series, vol. 178, American Geophysical Union, Washington, DC.

Ramondenc, P., L.N. Germanovich, K.L. Von Damm, and R.P. Lowell. 2006. The first measurements of hydrothermal heat output at $9^{\circ} 50^{\prime} \mathrm{N}$, East Pacific Rise. Earth and Planetary Science Letters 245:487-497, http://dx.doi.org/ 10.1016/j.epsl.2006.03.023.

Rona, P.A., and R. Light. 2011. Sonar images hydrothermal vents in seafloor observatory. Eos, Transactions, American Geophysical Union 92(20), http://dx.doi.org/10.1029/ 2011EO200002.

Rona, P.A., and D.A. Trivett. 1992. Discrete and diffuse flow heat transfer at ASHES vent field, Axial Volcano, Juan de Fuca Ridge. Earth and Planetary Science Letters 109:57-71, http:// dx.doi.org/10.1016/0012-821X(92)90074-6.

Rona, P.A., R.P. Denlinger, M.R. Fisk, K.J. Howard, G.L. Taghon, K.D. Klitgord, J.S. McClain, G.R. McMurray, and J.C. Wiltshire. 1990. Major off-axis hydrothermal activity on the northern Gorda Ridge. Geology 18:493-496, http://dx.doi.org/10.1130/0091-7613(1990) 018<0493:MOAHAO>2.3.CO;2.

Rudnicki, M.D., and H. Elderfield. 1992. Theory applied to the Mid-Atlantic Ridge hydrothermal plumes: The finite difference approach. Journal of Volcanology and Geothermal Research 50:161-172, http://dx.doi.org/ 10.1016/0377-0273(92)90043-D.

Sarrazin, J., P. Rodier, M.K. Tivey, H. Singh, A. Schultz, and P.M. Sarradin. 2009. A dual sensor device to estimate fluid flow velocity at diffuse hydrothermal vents. Deep Sea Research Part I 56:2,065-2,074, http://dx.doi.org/ 10.1016/j.dsr.2009.06.008.

Scheirer, D.S., T.M. Shank, and D.J. Fornari. 2006. Temperature variations at diffuse and focused flow hydrothermal vent sites along the northern East Pacific Rise. Geochemistry Geophysics Geosystems 7, Q03002, http://dx.doi.org/ 10.1029/2005GC001094.

Schultz, A., J.M. Delaney, and R.E. McDuff. 1992. On the partitioning of heat flux between diffuse and point source venting. Journal of Geophysical Research 97:12,229-12,314, http://dx.doi.org/ 10.1029/92JB00889.

Schultz, A., P. Dickson, and H. Elderfield. 1996. Temporal variations in diffuse hydrothermal flow at TAG. Geophysical Research Letters 23:3,471-3,474, http://dx.doi.org/ 10.1029/96GL02081.

Shank, T.M., D.J. Fornari, K.L. Von Damm, M.D. Lilley, R.M. Haymon, and R.A. Lutz. 1998. Temporal and spatial patterns of biological community development at nascent deep-sea hydrothermal vents $\left(9^{\circ} 50^{\prime} \mathrm{N}\right.$, East Pacific Rise). Deep-Sea Research Part II 45:465-515, http:// dx.doi.org/10.1016/S0967-0645(97)00089-1.

Sohn, R.A. 2007. Stochastic analysis of exit fluid temperature records from the active TAG hydrothermal mound (Mid-Atlantic Ridge, $\left.26^{\circ} \mathrm{N}\right): 1$. Modes of variability and implications for subsurface flow. Journal of Geophysical Research 112, B07101, http://dx.doi.org/ 10.1029/2006JB004435.

Tivey, M.K. 1995. Modeling chimney growth and associated fluid flow at seafloor hydrothermal vents sites. Pp. 158-177 in Seafloor Hydrothermal Systems: Physical, Chemical, Biological, and Geological Interactions. S.E. Humphris, R.A. Zierenberg, L.S. Mullineaux, and R.D. Thomson, eds, Geophysical Monograph Series, vol. 91, American Geophysical Union, Washington, DC.

Tivey, M.K. 2007. Generation of seafloor hydrothermal vent fluids and associated mineral deposits. Oceanography 20(1):50-65, http:// dx.doi.org/10.5670/oceanog.2007.80.

Tivey, M.K., A.M. Bradley, T.M. Joyce, and D. Kadko. 2002. Insights into tide-related variability at seafloor hydrothermal vents from time-series temperature measurements. Earth and Planetary Science Letters 202:693-707, http://dx.doi.org/10.1016/ S0012-821X(02)00801-4.

Trivett, D.A., and A.J. Williams III. 1994. Effluent from diffuse hydrothermal venting, Part 2: Measurement of plumes from diffuse hydrothermal vents at the southern Juan de Fuca Ridge. Journal of Geophysical Research 99:18,417-18,432, http://dx.doi.org/ 10.1029/94JC00096.

Tolstoy, M., F. Waldhauser, D.R. Bohnenstiehl, R.T. Weekly, and W.-Y. Kim. 2008. Seismic identification of along-axis hydrothermal flow on the East Pacific Rise. Nature 451:181-184, http://dx.doi.org/10.1038/nature06424.

Veirs, S.R., R.E. McDuff, and F.R. Stahr. 2006. Magnitude and variance of near-bottom horizontal heat flux at the Main Endeavour hydrothermal vent field. Geochemistry Geophysics Geosystems 7, Q02004, http://dx.doi.org/ 10.1029/2005GC000952.

Von Damm, K.L., and M.D. Lilley. 2004. Diffuse flow hydrothermal fluids from $9^{\circ} 50^{\prime} \mathrm{N}$ East Pacific Rise: Origin, evolution and biogeochemical controls. Pp. 245-268 in The Subseafloor Biosphere at Mid-Ocean Ridges. W.S.D. Wilcock, E.F. DeLong, D.S. Kelley, J.A. Baross, and S.C. Cary, eds, Geophysical Monograph Series, vol. 144, American Geophysical Union, Washington, DC.

Wankel, S.D., L.N. Germanovich, M.D. Lilley, G. Genc, C.J. DiPerna, A.S. Bradley, E.J. Olson, and P.R. Girguis. 2011. Influence of subsurface biosphere on geochemical fluxes from diffuse hydrothermal fluids. Nature Geoscience 4:461-468, http://dx.doi.org/ 10.1038/ngeo1183.

Wilcock, W.S.D., S.D. Archer, and G.M. Purdy. 2002. Microearthquakes on the Endeavour Segment of the Juan de Fuca Ridge. Journal of Geophysical Research 107(B12), 2336, http:// dx.doi.org/10.1029/2001JB000505. 